\title{
Foliar anatomical study of Boerhavia diffusa L.: a potent medicinal plant
}

Debasmita Dutta Pramanick ${ }^{*}$ and G. G. Maiti ${ }^{2}$

${ }^{1}$ Botanical Survey of India, CGO Complex, $3^{\text {rd }}$ MSO Building, DF Block, Salt Lake City, Sector-1, Kolkata, India. ${ }^{2}$ Taxonomic and Biosystematic Laboratory, Dept. of Botany, University of Kalyani, Kalyani-741 235, Kolkata, India.

Received: January 18, 2017; Accepted: February 21, 2017

\begin{abstract}
Boerhavia diffusa L. (Nyctaginaceae), commonly known as 'Punarnava', has a long history of multifarious uses in Indian system of medicine as well as ethno-medicinal system. The plant is widely distributed in tropical and subtropical countries of both the hemispheres. The plant in whole or aerial parts or roots, used widely by the indigenous people of India, are well reputed for anti-bacterial, hepato-protective, hypo-glycemic, anti-proliferative, anti-inflammatory, anti-convulsant and anti-stress properties. The present paper, deals with nodal and petiolar anatomical study of $B$. diffusa along with foliar architectural pattern, is an attempt to authenticate and reduce the adulteration to the crude drugs.
\end{abstract}

Key words: Boerbavia diffusa L.; Foliar-architectural pattern; Medicinal uses

\section{Introduction}

Boerhavia diffusa L., commonly known as 'Punarnava', belongs to the family Nyctaginaceae, is widely used in the indigenous system of medicine since the time immemorial. The genus Boerbavia L. is a pantropical taxon of which $B$. diffusa $\mathrm{L}$. is of cosmopolitan distribution in both the hemispheres. In India, the plant grows abundantly as ruderal weed. The therapeutic uses of the drug plant was even mentioned in the 'Vidaryadi gana' of 'Vagbhata', 'Puranas', 'Nighantu', 'Rajnighantu', 'Bhavaprakash', 'Charaka Samhita', 'Sushrata Samhita' and in different Tibbi literature. Although root is the major officinal part, village people, tribal and aboriginal communities of India use different parts of the drug plant in the treatment of various ailments viz. Heart disease, Anaemia, Asthma, Cough \& cold, Tumours, enlargement of spleen of children, abdominal pain, Dropsy, Dyspepsia, Sprains, Diuretic, Laxative, Hepatitis, Dropsical swellings, Urethritis, Night blindness, Beri-beri, Epilepsy, Fistula, Muscular pain, Elephantiasis, Paralysis etc. (Chopra et al., 1956; Chunekar, 1982; Guha-Bakshi et al., 1999; Watt, 1972). Although B. diffusa L. is botanically equated with the drug plant 'Punarnava' due to presence of major active constituents 'Punarnavines' and 'Boerhavinones' but taxonomic controversies lies regarding identification of the plant since long. In spite of presence of differential active principles, due to lacking of sharp morphological differences, other species of Boerhavia L. are often used (adulterated) as 'Punarnava' in different regions of India.

The anatomical study of the family Nyctaginaceae was first done by Solereder (1908) and then by Metcalfe \& Chalk (1950) as a general account of anatomical features. A very scanty works had been done on foliar-vasculature pattern along with node-petiole anatomy of

\section{*Corresponding Author:}

Dr. Debasmita Dutta Pramanick,

Scientist, Publication Section,

Botanical Survey of India, Ministry of Environment,

Forest \& Climate Change, Kolkata - 700064, India.

E-mail: debasmita.bot@gmail.com
Nyctaginaceous members. Hickey (1973), Melville (1969, 1976) and Dilcher (1974) have emphasized on the characters of foliar venation pattern and their importance in taxonomic study. Nair \& Nair (1961) worked on morphology of some members of Nyctaginaceae with special reference to nodal anatomical features of the genus Boerbavia L. Howard (1979) also stressed on importance of the characters of nodal and petiolar structures in solving taxonomic controversies. In order to contribute to the medicinal plant and crude drug identification and mitigation of common adulterants, present foliar-anatomical investigation is attempted.

\section{Material and Methods}

The present study is mainly based on herbarium specimens deposited in the renowned herbaria in India (CAL, MH, ASSAM, DD, BSD, PBL, LWG, TBGT, RHT) and on the basis of several live specimens collected from different states of India. The voucher specimens are deposited in Central National Herbarium (CAL). Table 1

Table 1: List of studied specimens for foliar venation and node-petiolar anatomy

\begin{tabular}{|c|c|}
\hline $\begin{array}{l}\text { Name of } \\
\text { the Species }\end{array}$ & Coll. No. and other Details \\
\hline $\begin{array}{l}\text { Boerhavia } \\
\text { diffusa } \mathrm{L} .\end{array}$ & $\begin{array}{l}\text { Andhra Pradesh, Hyderabad Dist., along Moosi } \\
\text { river bank, 24.06.1958, Sebastine 5942 (MH); } \\
\text { Nagarjuna Bonda Valley, Walley, 13.07.1961, } \\
\text { Thothathri } 9614 \text { (CAL); Assam, Mikir hills Dist., } \\
\text { Tamulbari unclassified Forest, Diphu, 24.06.1963, } \\
\text { Deb } 35303 \text { (ASSAM); Kerala, } \\
\text { Thiruvananthapuram, TBGRI Campus, 16.01.2016, } \\
\text { D. Pramanick 38409(CAL, MH); TamilNadu, } \\
\text { Coimbatore, T.N.A.U Campus, 24.01.2006, D. } \\
\text { Pramanick 38421(MH); West Bengal, Howrah, } \\
\text { Andul, Jhorehat, 18.02.2009, } 38430 \text { (CAL) }\end{array}$ \\
\hline
\end{tabular}

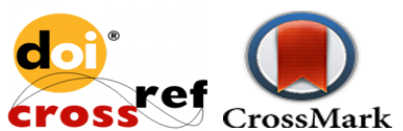


For anatomical studies, young nodal portion along with fully mature lamina with petioles were selected to get the continuation of vascularization pattern. The materials were preserved in F.A.A. solution for 2-5 days to remove the pigment and alcohol soluble components. The materials were then transferred to $5 \% \mathrm{NaOH}$ soln. for 12-24 hours for softening the fibres. Serial sections were cut at the nodal regions of stems, in the proximal, middle and distal parts of petioles either by hands or by microtome. Permanent slides were prepared by following regular dehydration and passing through xylol soln.; 2\% safranine and 2\% light green were used for staining purpose. Permanent slides were prepared mounting with Canada balsam.

For the study of foliar-architectural pattern, either entire lamina or a portion of the lamina $\left(2 / 3^{\text {rd }}\right.$ from the base and $1 / 3^{\text {rd }}$ from apex) were selected and soaked in water overnight (for dried specimens). The experimental materials were transferred to $2.5 \% \mathrm{NaOH}$ soln. for bleaching purpose. After that the cleared materials were transferred to chloral hydrate soln. following Arnott (1959) and finally stained in 1\% aqueous safranine soln. Permanent slides were prepared through gradual dehydration and mounted in Canada balsam. For representation of the vein order upto $3^{\circ}$, higher magnification ( $\mathrm{x} 10, \mathrm{x} 40$, and $\mathrm{x} 100)$ of the microscope was used. Drawings were made using camera lucida. The foliar anatomical pattern was described following Metcalfe \& Chalk (1950), Hickey (1973), Dilcher (1974), Melville (1976) and Pole (1991).

\section{Results}

\section{Morphology}

Boerhavia diffusa L., a member of the family Nyctaginaceae, is a prostrate or diffuse, puberulous to glabrous herb with fusiform root. Leaves are ovatelanceolate, adaxial surface green, abaxial surface white, with red marginal glands; petiolate. Flower 1-12 together in cymose panicles, campanulate, pedicelled. Perianth mauve, red, pink or white. Anthocarp fusiform, 5ribbed, glandular.

\section{Foliar-anatomical features}

The genus Boerhavia L. is characterised by trilacunar, 3traced node. In transverse section petiolar traces varies from 5-7 in different species. In $B$. diffusa, proximal end of petiole is with 7 vascular traces of which lateral two are larger, inner 3 median and outermost 2 smaller, all ectophloic, phloem on outer side of the xylem, semilunar arrangement; middle region with the same configuration but the median traces more compact and fused with each other. Distal end with 9 traces due to division of lateral traces.

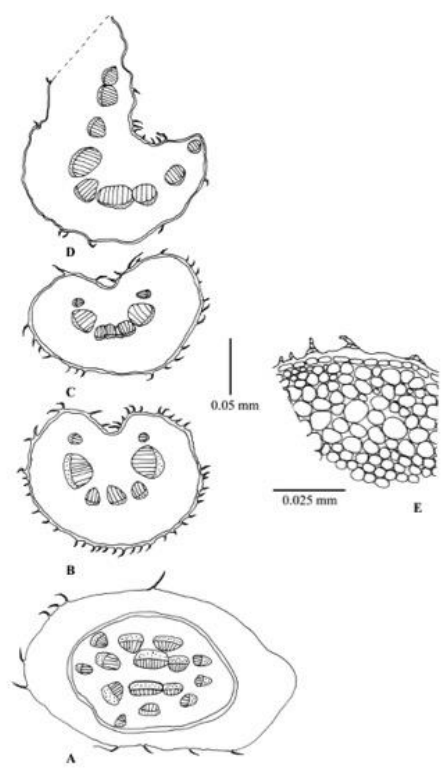

Fig.1: Boerhavia diffusa L.:A. Transverse section (t.s.) of node (Diagrammatic); B.-D. Transverse section of petiole-B. Proximal end; C. Middle region; D. Distal end; E. Cellular features of the petiolar section at proximal end.

Regarding cellular composition, epidermis is 1-cell layered thick; cells rectangular to barrel-shaped, thin walled, compact, covered with thick cuticle and multicellular trichomes; cortex massive, parenchymatous, cells rounded, isodiametric, more or less compact with less intercellular spaces.

\section{Foliar-venation pattern}

Major venation pattern in the genus Boerhavia L. is brochidodromous type. The primary vein $\left(1^{\circ}\right)$ is one, passing through the median region of lamina, moderately stout, staright and unbranched. In B.diffusa, secondary veins $\left(2^{\circ}\right)$ are 4-5 pairs on either side of the mid-vein, mostly alternate while the basal pair is opposite. The angle of divergence of basal pair and other pairs is acute $\left(60^{\circ}\right)$ but in upper pairs of secondaries are less acute than the lower pairs. All are moderately thick, abruptly curved and joining with the superadjacent secondaries at acute angle at the lowermost pair and at right angle at the upper pairs in the intramarginal region. Arches are found in the intramarginal region and usually 3-4 tiers. Intramarginal vein and intersecondary vein both are absent. Outersecondary veins are formed from the basal pairs of secondary veins with 3-5 successive loops and all of them are joining to their superadjacent ones. Tertiary veins $\left(3^{\circ}\right)$ are of interangular, joining and often cascade pattern. Interangular veins 2-3, curved, convex, with equal or unequal arms and the longer arms facing towards primary vein and the shorter arms towards subadjacent secondaries. Angles of origin of interangular veins at admedial side is mostly right $(R)$ sometimes obtuse $(\mathrm{O})$ and acute $(\mathrm{A})$ and to the exmedial side is mostly obtuse $(\mathrm{O})$ and then right $(\mathrm{R})$ forming different combinations of RO, RR, OO, OR, AR, and AO. The 
joining veins are very few with the angle of origin at the admedial side is acute (A) and at the exmedial side is acute (A) forming the combination of AA. These are 12 , towards lower part, sparce, unbranched, convex and forming oblique nature with the midvein. Cascade pattern is in maximum region within the loops of secondaries and forming usually network and interconnecting, both lax and close.

Venation is up to $5^{\circ}$ order, rare often up to $6^{\circ}$ order and gradually thinner to the higher orders, relatively lax and randomly oriented. Both Quaternary vein $\left(4^{\circ}\right)$ and quinternary veins $\left(5^{\circ}\right)$ are thin, randomly oriented. Areoles are formed irregularly by the union of $3^{\circ}, 4^{\circ}$ and $5^{\circ}$ orders of veins. The areoles are irregular in shape and sizes and with the free vein endings within most of the areoles. Free vein endings are 1 to 3 , long or mediumsized, curved, unbranched or dichotomously branched extending middle or more than middle of the areolar space. Each one is consisting of spirally thickened elongated 1 to 3 tracheids, totally ensheathed with parenchymatous sheath cells. The ultimate ends of the free vein endings or the very tips of the veinlets are mostly dichotomously branched. There are sometimes smaller loops which are devoid of any free vein endings. The sheath cells are somewhat oblong in shape, thinwalled, more or less loosely arranged. Marginal venation is incomplete, associated with free vein endings often with the loops. The free vein endings are simple and curved or straight with branching pattern as centric. The formation of areoles is alike to the laminar part.

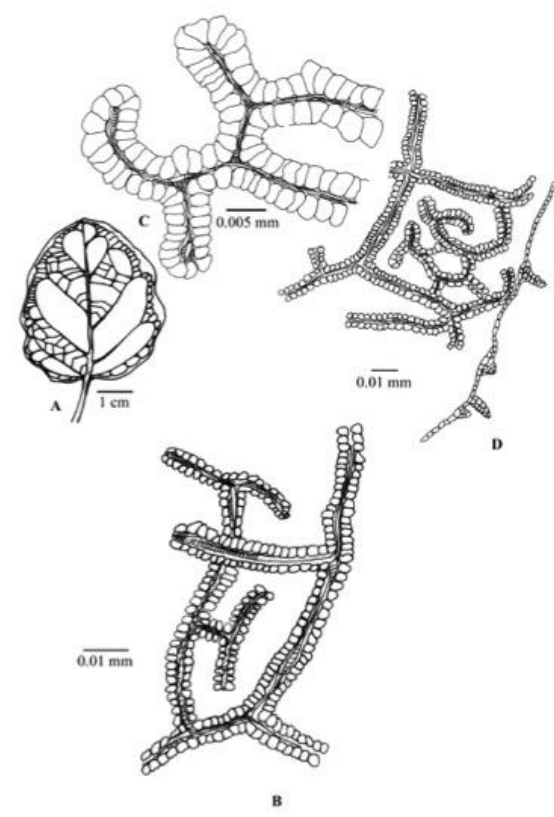

Fig. 2: Boerhavia diffusa L.: A. Major Venation; B. Venation pattern; C. Free vein ending; D. Marginal venation.

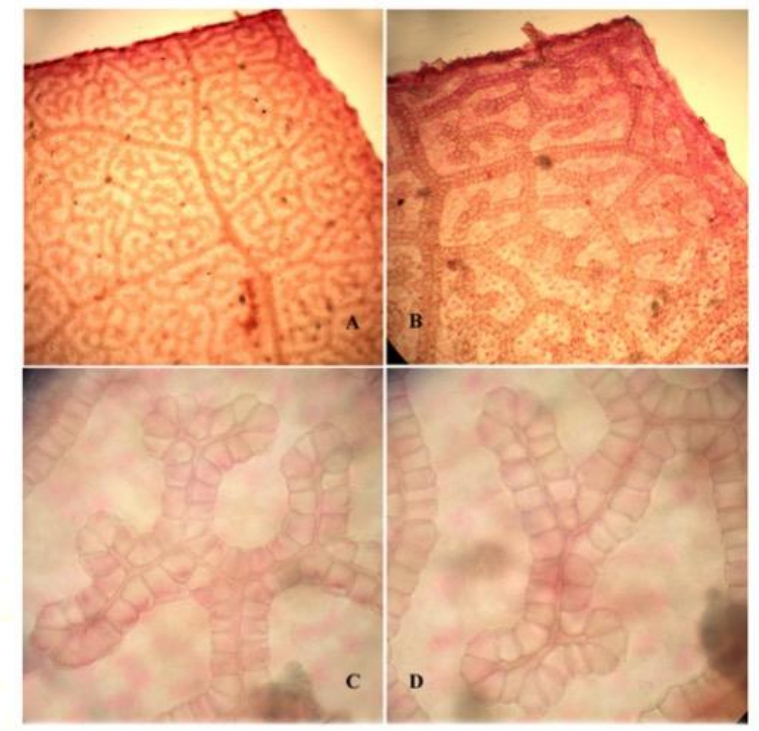

Plate 1: Boerhavia diffusa L.: A.Venation pattern (4x); B. Venation pattern magnified showing vascular sheath cells $(10 \mathrm{x})$; C.\&D. Free vein ending with distinct sheath cells $(40 \mathrm{x})$.

\section{Discussion and Conclusion}

The genus Boerbavia L. is taxonomically quite significant as controversies lies regarding identification as well as inclusion and exclusion of number of species since decades. As most of the members of the genus are extreamly polymorphic thus morphological differentiation at species level is often painstaking. However, the identity of the studied species, has already been established on the basis of morpho-taxonomic features, is always not so much convincing. The present study is an additional support towards establishment of their identity of the species and mitigation of common adulterants. The present study reveals that among four species of Boerhavia L., (B. crispa Heyne ex Hook. f., B. diffusa L., B. erecta L. \& B. rubicunda Steud.) B. diffusa L. possessess some unique features as lateral two larger traces, inner three median traces, outermost two smaller traces, free vein endings with 1-3 spirally thickened, elongated tracheids, bulbous, swelled sheath cells and incomplete marginal venation) which specifically authenticate the drug plant from other substituents.

\section{References}

1. Arnot HJ. Leaf clearing, Turtex Nens, 37 (1959): 192-194.

2. Chopra RN, SL Nayar and IC Chopra. Glossary of Indian Medicinal Plants, Council of Scientific and Industrial Research, New Delhi, (1956), pp 39.

3. Chunekar KC. Bhavaprakasa Nighantu, Chaukhambha Bharti Academy, Varanasi, India, (1982), pp 498.

4. Dilcher DL. Approaches to the identification of Angiosperm leaf remains, 40 Bot. Rev. (1974): 1-157.

5. Guha Bakshi DN, P. Sen Sarma and DC Pal. A Lexicon of Medicinal Plants in India, Vol.1, Naya Prakash, Calcutta, (1999), pp 294-297. 
6. Hickey LJ. Classification of the architecture of Dicotyledonous leaves. 60, Amer. J. Bot., 60 (1973): 17-33.

7. Howard RA. The petiole, In Anatomy of the Dicotyledons, ed. Metcalfe, CR, Chalk L, Vol. 1, Clarendon Press, Oxford, (1979), 88-96.

8. Melville R. Leaf venation patterns and the origin of the Angiosperms, 224 Nature 1969: 121-125.

9. Melville R. The terminology of leaf architecture, 25(5 \& 6) Taxon, (1976): 549-561.

10. Metcalfe CR, and L. Chalk. Anatomy of the Dicotyledons, Vol. 2, Clarendon Press, Oxford, (1950), pp. 1059-1067.

11. Nair NC and VJ Nair. Studies on the morphology of some members of the Nyctaginaceae I, Nodal anatomy of Boerhavia, 54 Proc. Indian Acad. Sci. B., (1961): 281-294.
12. Pole M. A modified terminology for angiosperm leaf architecture, 21(4) J. Royal Soc. New Zealand, (1991): 297 312.

13. Solereder H. Systematic anatomy of the Dicotyledons: A handbook for Laboratories of Pure and Applied Botany, Clarendon Press, Oxford, (1908), vol.2, pp. 645-649.

14. Watt G. A Dictionary of the Economic Products of India, Vol. 1, Periodical Experts, Delhi, (1972), pp 485.

\section{Cite this article as:}

Debasmita Dutta Pramanick and G. G. Maiti. Foliar anatomical study of Boerbavia diffusa L.: a potent medicinal plant. Annals of Plant Sciences 6.02 (2017): 1598-1601. DOI: http://dx.doi.org/10.21746/aps.2017.04.001 